\title{
The relationship between organizational development and teacher performance?
}

\author{
Nellitawati Nellitawati \\ ${ }^{1}$ Universitas Negeri Padang, Indonesia \\ *) Corresponding author, $\triangleq e$-mail: nellitawati@fip.unp.ac.id
}

\begin{abstract}
This study analyzes the contribution of the principal's organizational development to teacher performance. It uses a descriptive correlational method, with a total sample of 86 teachers. The study used organizational development and teacher performance questionnaires for data collection. The analysis of data were based on partial correlation and multiple linear regression techniques. According to the results, organizational development has a significant influence on teacher performance.
\end{abstract}

Keywords: Organizational development, teacher performance, principal

How to Cite: Nellitawati, N. (2019). How does organizational development contribute to teacher performance?. COUNS-EDU: The International Journal of Counseling and Education, 4(4), 157-162. DOI: http://doi.org/10.23916/0020190425240

This is an open access article distributed under the Creative Commons Attribution License, which permits unrestricted use, distribution, and reproduction in any medium, provided the original work is properly cited. (C2019 by author.

\section{Introduction}

Employees are expected to perform satisfactorily and maximally contribute to the achievement of the goals of the organization. Performance is the appropriateness of work results in relation to the expected standards (Christian, Garza, \& Slaughter, 2011; Tierney \& Farmer, 2011). In general, it is driven by a motive to achieve under workloads based on the skills, experience, and the commitment of the concerned employees (Cohen, Dierkes, \& Bradley, 2011). Also, performance can be defined as a result achieved by certain functions and positions within a specified period based on the level of achievement of organizational goals (Buller \& McEvoy, 2012; Dobre, 2013).

A school is an organization with specific goals, objectives, visions, and missions that need to be realized. It requires a superb performance since teachers are form part of its structure (Darling-Hammond, 2010; Dee \& Wyckoff, 2015; West, 2013). Performance refers to the outcome of implementing professional and functional tasks in learning over a certain period (Guarino, Reckase, \& Wooldridge, 2015; Taylor \& Tyler, 2012; Woessmann, 2011). It involves implementing tasks assigned to teachers based on ability, experience, seriousness, and the use of time to accomplish responsibilities.

For the tasks and responsibilities to follow predetermined standards, there is a need for organizational development support, mainly from the principal (Ball, 2012; Reynolds, 2010). Organizational development encourage stakeholders in the school to work optimally and create excellent performance (Benn, Edwards, \& Williams, 2014; Gable \& Wolf, 2012; Horner, Sugai, \& Anderson, 2010). An inappropriate organization development hampers the implementation of work and hurts performance (Benn, et al., 2014; Cummings \& Worley, 2014).

Although teachers are expected to perform based on the set standards, they often do not achieve (Elliott, 2015; Harris \& Sass, 2014; Hyslop-Margison \& Sears, 2010). Organizational development needs to guide the actions of every teacher to improve productivity (Thoonen, Sleegers, Oort, Peetsma, \& Geijsel, 2011). It is a planned effort initiated by process experts to help an organization develop its diagnostic skills, 
mastery abilities, relationship strategies in the form of temporary or half-fixed systems, and cultural equality (Boyd, 2010; Cummings \& Worley, 2014; Lewis, Cantore, \& Passmore, 2016). In general organizational development is a set of interventions built on democratic humanistic values to improve effectiveness and welfare of employees (Anderson, 2019; Benn, et al., 2014; Boyd, 2010). It aims to create order in the organization to improve effectiveness through planned interventions with behavioral science. Therefore, this study analyzes the contribution of organizational development to teacher performance.

\section{Method}

This study uses quantitative non-experimental methods (Blundell \& Costa Dias, 2000), which are descriptive and correlational (Lappe, 2000) to determine the contribution between two variables by measuring the coefficient and its significance. The population included all teachers in Nanggalo District Elementary School, with a total sample of 86. Data collection uses teacher performance and organizational development questionnaires. Also, simple regression and correlation techniques are used to analyze data.

\section{Result and Discussions}

\section{Descriptive analysis}

Teacher performance

The teacher performance questionnaire comprised of 37 items. The minimum and maximum scores are 37 and 259, respectively. Based on respondents' answers, the lowest and the highest scores are 187 and 229 , respectively. The average data processing score was 206.80, while mode and median are 199 and 207, with a standard deviation of 9.422 . The average score price, mode, and median is not much different and does not exceed one standard deviation. This means that the distribution of teacher performance is normal. An illustration of the frequency distribution of teacher performance scores is shown in Table 1:

Table 1. Frequency distribution of teacher performance scores

\begin{tabular}{ccc}
\hline Interval Class & Frequency & \% \\
\hline $\mathbf{1 8 7}-\mathbf{1 9 2}$ & 4 & 4.65 \\
$\mathbf{1 9 3}-\mathbf{1 9 8}$ & 11 & 12.79 \\
$\mathbf{1 9 9}-\mathbf{2 0 4}$ & $\mathbf{2 2}$ & $\mathbf{2 5 . 5 8}$ \\
$\mathbf{2 0 5}-\mathbf{2 1 0}$ & 20 & 23.26 \\
$\mathbf{2 1 1}-\mathbf{2 1 6}$ & 15 & 17.44 \\
$\mathbf{2 1 7}-\mathbf{2 2 2}$ & 10 & 11.63 \\
$\mathbf{2 2 3}-\mathbf{2 2 8}$ & 3 & 3.49 \\
$\mathbf{2 2 9}-\mathbf{2 3 4}$ & 1 & 1.16 \\
Sum & 86 & \\
\hline
\end{tabular}

Based on the calculations in Table 1, the frequency of teacher performance is $25.58 \%$. The table shows that $17.44 \%$, and $82.56 \%$ of respondents scored below and above the average value respectively. The difference in average score, median, and mode does not exceed one standard deviation, and the distribution of teacher performance data is normal.

The level of achievement of respondents' scores on teacher performance was $89.90 \%$, which is in a good category. Therefore, teacher performance is in a good category. The results of the analysis of the level of achievement of each teacher performance indicator are presented in Table 2 below. 
Table 2. The level of achievement of the respondents per teacher performance indicator

\begin{tabular}{|c|c|c|c|c|c|}
\hline No & Indicator & $\begin{array}{l}\text { Ideal } \\
\text { Score }\end{array}$ & Average Score & $\%$ & Category \\
\hline 1 & $\begin{array}{l}\text { Make a draft } \\
\text { implementation of } \\
\text { learning }\end{array}$ & 56 & 48.80 & $87.15 \%$ & Good \\
\hline 2 & $\begin{array}{l}\text { Carry out the learning } \\
\text { process }\end{array}$ & 49 & 43.33 & $88.42 \%$ & Good \\
\hline 3 & Manage class & 35 & 29.77 & $85.05 \%$ & Good \\
\hline 4 & $\begin{array}{l}\text { Professional development } \\
\text { and additional tasks }\end{array}$ & 55 & 42.94 & $78.08 \%$ & Good Enough \\
\hline \multirow[t]{2}{*}{5} & $\begin{array}{l}\text { Professional } \\
\text { responsibility }\end{array}$ & 54 & 41.97 & $77.71 \%$ & Good Enough \\
\hline & & & & $89.04 \%$ & Good \\
\hline
\end{tabular}

Based on table 2, there are three indicators in both good and sufficient categories. However, the two indicators in the sufficient category still need to be increased, including a professional responsibility, which indicates performance. Essentially, teacher performance will not be good in case the professional responsibilities are not carried out (Ambrosetti, 2011; Dang, 2013; Taylor \& Tyler, 2012). This principle of responsibility is an obligation that all professionals need to fulfill.

The organizational development questionnaire comprised of 37 items. The minimum and the maximum scores were 36 and 252, respectively. Based on respondents' answers, the lowest and the highest scores were 185 and 238, respectively. From the results, the mean score was 213.97. Additionally, mode and median were 211 and 213.00 , respectively, with a standard deviation of 10,345 . The average score value, mode, the median were not much different and did not exceed one standard deviation. This means that the distribution of organizational development is normal. An illustration of the frequency distribution of teacher performance scores is shown in Table 3:

Table 3. Frequency distribution of organizational development scores

\begin{tabular}{ccc}
\hline $\begin{array}{c}\text { Interval } \\
\text { Class }\end{array}$ & Fo & \% Fo \\
\hline $\mathbf{1 8 5}-\mathbf{1 9 1}$ & 1 & 1.17 \\
$\mathbf{1 9 2}-\mathbf{1 9 8}$ & 6 & 6.98 \\
$\mathbf{1 9 9}-\mathbf{2 0 5}$ & 13 & 15.12 \\
$\mathbf{2 0 6}-\mathbf{2 1 2}$ & $\mathbf{2 1}$ & $\mathbf{2 4 . 4 2}$ \\
$\mathbf{2 1 3}-\mathbf{2 1 9}$ & 19 & 22.09 \\
$\mathbf{2 2 0}-\mathbf{2 2 6}$ & 17 & 19.77 \\
$\mathbf{2 2 7}-\mathbf{2 3 3}$ & 7 & 8.14 \\
$\mathbf{2 3 4}-\mathbf{2 4 0}$ & 2 & 2.33 \\
Sum & $\mathbf{8 6}$ & \\
\hline
\end{tabular}

Based on Table 3, the frequency of organizational development is $21(24.42 \%)$ of the number of respondents with an average score. Also, $20(23.27 \%)$ and $66(76.73 \%)$ respondents scored below and above the average value, respectively. Since the difference in average score, median and mode do not exceed one standard deviation, the distribution of organizational development data is normal. The level of achievement of respondents for each indicator of organizational development is presented in Table 4. 
Table 4. Level of achievement of respondents for each indicator of organizational development

\begin{tabular}{llcccc}
\hline No & \multicolumn{1}{c}{ Indicators } & $\begin{array}{c}\text { Ideal } \\
\text { Score }\end{array}$ & $\begin{array}{c}\text { Average } \\
\text { Score }\end{array}$ & $\mathbf{\%}$ & Category \\
\hline $\mathbf{1}$ & Change intervention & 56 & 51.16 & $89.36 \%$ & Good \\
$\mathbf{2}$ & Data collection process & 42 & 37.74 & $89.87 \%$ & Good \\
$\mathbf{3}$ & Action planning & 35 & 31.02 & $88.6 \%$ & Good \\
$\mathbf{4}$ & Develop diagnostic skills & 49 & 38.37 & $78.5 \%$ & Enough \\
$\mathbf{5}$ & Develop mastery skills & 34 & 28.45 & $83.7 \%$ & Good \\
$\mathbf{6}$ & Develop a relationship strategy & 35 & 27.12 & $77.42 \%$ & Enough \\
& & & & $\mathbf{8 9 . 9 0 \%}$ & Good \\
\hline
\end{tabular}

From Table 4., 4 indicators are in a good category, while 2 are in a sufficient category. This means that these two indicators still need to be improved. The first and second indicators develop diagnostic skills and a relationship strategy, respectively. Developing relationship strategies in organizational development are the main things that need to be prioritized (Kraimer, Seibert, Wayne, Liden, \& Bravo, 2011; LengnickHall, Beck, \& Lengnick-Hall, 2011). However, the results show it is in a sufficient category, and therefore, there is a need to improve it. In an organization, building relationships between workers is one of the determining factors for goal achievement. A good relationship between members fosters mutual respect, care, and support, forming strong cooperation.

\section{Normality test}

Testing the normality of the teacher performance, variable scores, and development, was based on the Kolmogorov Smirnov-Z technique (SPSS program version 20). Data is said to be generally distributed in case K-S has a significant level (asymp. sig) $>0.05$. Suppose the significance level (asymp. sig) $<0.05$, then the data are not normally distributed. The results of the examination are in Table 5:

Table 5. Summary of normality test results

\begin{tabular}{lccc}
\hline & $\begin{array}{c}\text { Teacher } \\
\text { Performance }\end{array}$ & $\begin{array}{c}\text { Organizational } \\
\text { Development }\end{array}$ & $\begin{array}{c}\text { Democratic } \\
\text { Leadership Style }\end{array}$ \\
\hline Kolmogorov-Smirnov Z & 0.740 & 0.679 & 1.004 \\
$\mathbf{P}$ & 0.643 & 0.745 & 0.265 \\
\hline
\end{tabular}

From Table 5, the significance value of each variable is greater than alpha 0.05 . Therefore, the data normality has been fulfilled.

\section{Homogeneity Test}

The homogeneity test is carried out to determine the similarity of variance tied to teacher performance variables using the Levene test method. In case the significant value is over 0.05 , the variants of two or more data groups are the same. The homogeneity test using the Leven technique with SPSS version 20.00 involves looking at the asymp.sig value $>0.05$, which means the research data is from the same variance (homogeneous). In case the asmp.sig value $<0.05$, the research data is from unequal variance as shown in Table 6.

Table 6. Results of the variance similarity test

\begin{tabular}{lccc}
\hline Prices for groups & Levene Statistic & Sig. & Conclusion \\
\hline Organizational Development & 2,358 & 0,006 & Homogenous \\
\hline
\end{tabular}

The results of teacher performance calculations on organizational development are homogeneous.

\section{Linearity test}

This regression test is conducted to determine the data of organizational development in terms of linear lines against teacher performance. Decisions regarding a linear regression line are assessed through the $\mathrm{F}$ 
test with a significance level of 0.05 . The results of the intermediate linearity tests are presented in Table 7 below.

Table 7. Summary of the results of the linearity test analysis

\begin{tabular}{lccrrr}
\hline \multicolumn{1}{c}{ Source } & Number of Squares & Dk & RJK & F & P \\
\hline Deviation & 2573.881 & 33 & 77.996 & .872 & .658 \\
In Group & 4563.389 & 51 & 89.478 & & \\
Total & 7545.6488 & 85 & & & \\
\hline
\end{tabular}

In Table 7, the price $\mathrm{F}=0.872$ with $\rho=0.658(\rho>0.05)$ means that the regression equation is linear.

\section{Contribution of organizational development to teacher performance}

The results show that organizational development significantly contributes to teacher performance, precisely with $5.4 \%$. The regression equation obtained between the development and teacher performance is $=161.48+0.212 \mathrm{X} 1$. This shows that when $\mathrm{X} 1$ has not affected $\mathrm{Y}$, the value is 161.48 , and when $\mathrm{X} 1$ influences $\mathrm{Y}$, it changes to $161.48+0.212$. The regression equation shows that organizational development contributes significantly to teacher performance. Organizational development needs to be increased to enhance teacher performance through new policies and strategies.

\section{Conclusion}

Organizational development in this study was included in both good and sufficient categories, with a contribution of $5.4 \%$ to teachers' performance in Nanggalo District Elementary School by $5.4 \%$. This means that organizational development has a significant positive contribution to teacher's performance in schools.

\section{References}

Ambrosetti, A. (2011). Mentoring relationships, roles and responsibilities in pre-service teacher professional placements. Paper presented at the AARE Annual Conference, Hobart.

Anderson, D. L. (2019). Organization development: The process of leading organizational change: SAGE Publications, Incorporated.

Ball, S. J. (2012). The micro-politics of the school: Towards a theory of school organization: Routledge.

Benn, S., Edwards, M., \& Williams, T. (2014). Organizational change for corporate sustainability: Routledge.

Blundell, R., \& Costa Dias, M. (2000). Evaluation methods for non-experimental data. Fiscal studies, 21(4), 427-468.

Boyd, N. M. (2010). Organization development in community contexts. Journal of prevention \& intervention in the community, 39(1), 1-4.

Buller, P. F., \& McEvoy, G. M. (2012). Strategy, human resource management and performance: Sharpening line of sight. Human resource management review, 22(1), 43-56.

Christian, M. S., Garza, A. S., \& Slaughter, J. E. (2011). Work engagement: A quantitative review and test of its relations with task and contextual performance. Personnel psychology, 64(1), 89-136.

Cohen, P. D., Dierkes, G. A., \& Bradley, A. D. (2011). Facilitating performance of submitted tasks by mobile task performers: Google Patents.

Cummings, T. G., \& Worley, C. G. (2014). Organization development and change: Cengage learning.

Dang, T. K. A. (2013). Identity in activity: Examining teacher professional identity formation in the paired-placement of student teachers. Teaching and teacher education, 30, 47-59.

Darling-Hammond, L. (2010). Evaluating teacher effectiveness: How teacher performance assessments can measure and improve teaching. Center for American Progress.

Dee, T. S., \& Wyckoff, J. (2015). Incentives, selection, and teacher performance: Evidence from IMPACT. Journal of Policy Analysis and Management, 34(2), 267-297.

Dobre, O.-I. (2013). Employee motivation and organizational performance. Review of applied socio-economic research, 5(1).

Elliott, K. (2015). Teacher Performance Appraisal: More about Performance or Development? Australian Journal of teacher education, 40(9), n9.

Gable, R. K., \& Wolf, M. B. (2012). Instrument development in the affective domain: Measuring attitudes and values in corporate and school settings (Vol. 36): Springer Science \& Business Media. 
Guarino, C. M., Reckase, M. D., \& Wooldridge, J. M. (2015). Can value-added measures of teacher performance be trusted? Education Finance and Policy, 10(1), 117-156.

Harris, D. N., \& Sass, T. R. (2014). Skills, productivity and the evaluation of teacher performance. Economics of Education Review, 40, 183-204.

Horner, R. H., Sugai, G., \& Anderson, C. M. (2010). Examining the evidence base for school-wide positive behavior support. Focus on exceptional children, 42(8).

Hyslop-Margison, E. J., \& Sears, A. M. (2010). Enhancing teacher performance: The role of professional autonomy. Interchange, 41(1), 1-15.

Kraimer, M. L., Seibert, S. E., Wayne, S. J., Liden, R. C., \& Bravo, J. (2011). Antecedents and outcomes of organizational support for development: The critical role of career opportunities. Journal of Applied Psychology, 96(3), 485.

Lappe, J. M. (2000). Taking the mystery out of research: Descriptive correlational design. Orthopaedic Nursing, 19(2), 81.

Lengnick-Hall, C. A., Beck, T. E., \& Lengnick-Hall, M. L. (2011). Developing a capacity for organizational resilience through strategic human resource management. Human resource management review, 21(3), 243-255.

Lewis, S., Cantore, S., \& Passmore, J. (2016). Appreciative inquiry for change management: Using AI to facilitate organizational development: Kogan Page Publishers.

Reynolds, D. (2010). School effectiveness: A\&C Black.

Taylor, E. S., \& Tyler, J. H. (2012). The effect of evaluation on teacher performance. American Economic Review, 102(7), 3628-3651.

Thoonen, E. E., Sleegers, P. J., Oort, F. J., Peetsma, T. T., \& Geijsel, F. P. (2011). How to improve teaching practices: The role of teacher motivation, organizational factors, and leadership practices. Educational administration quarterly, 47(3), 496-536.

Tierney, P., \& Farmer, S. M. (2011). Creative self-efficacy development and creative performance over time. Journal of Applied Psychology, 96(2), 277.

West, C. (2013). The 6 keys to teacher engagement: Unlocking the doors to top teacher performance: Routledge.

Woessmann, L. (2011). Cross-country evidence on teacher performance pay. Economics of Education Review, 30(3), 404-418. 